\title{
Evaluation of Arginine and Tryptophan In Ovo Feeding on Production Performances, Glycogen Status, Intestinal Health and Immunity Related Gene Expression in Fast Growing Broilers
}

Nibedita Nayak ( $\nabla$ drnibeditavet@gmail.com )

ICAR Central Coastal Agricultural Research Institute https://orcid.org/0000-0001-5643-3831

R. Asha Rajini

Madras Veterinary College

Amiya Ranjan Sahu

ICAR Central Coastal Agricultural Research Institute

J. John Kirubaharan

Madras Veterinary College

S. Ezhilvalavan

Madras Veterinary College

\section{Research Article}

Keywords: In ovo nutrition, Arginine and Tryptophan, Glycogen status, Gut health, Immune response, Fastgrowing broilers

Posted Date: February 4th, 2022

DOl: https://doi.org/10.21203/rs.3.rs-1169976/v1

License: (c) (1) This work is licensed under a Creative Commons Attribution 4.0 International License.

Read Full License 


\section{Abstract}

The aim of this study was to evaluate the impact of in ovo feeding of essential amino acids (arginine and tryptophan) on post-hatch growth performances, organ indices, glycogen status, intestinal health, immune response and immunity related gene expression in fast-growing broilers. Total 700 fertile eggs (Cobb-400) divided into five groups and in ovo injection of arginine and/or tryptophan was administered on $18 \mathrm{~d}$ of incubation through amnion to a depth of about $8 \mathrm{~mm}$, sealed with paraffin wax and seted for hatching. Arginine feeding had significantly $(P<0.01)$ improved hatch weight, chick/egg weight ratio and placement weight. Body weight gain was observed up to $21 \mathrm{~d}$ of age in arginine fed group, while till $14 \mathrm{~d}$ in combination group. Arginine had improved eviscerated and ready-to-cook weight significantly $(\mathrm{P}<0.01)$, but tryptophan increases breast yield per cent. Liver glycogen was significantly $(P<0.01)$ higher in arginine fed groups. On $4 d$, villi height was significantly $(P<0.05)$ increased in duodenum and ileum in all amino acid fed groups. On 35d, villi height was improved in duodenum and jejunum in tryptophan and combination groups. Higher $\mathrm{HI}$-titre was observed on 4d in Arginine group; however, combination group had better HI-titre on 21 and 35d due to humoral immunity. IL-8 gene had high expression in tryptophan group, while IFN-y expressed more in combination group. Hence, arginine and tryptophan in ovo feeding had improved production performances, glycogen status, intestinal health and immune response after proper metabolism over the feeding in day old chicks.

\section{Introduction}

In ovo feeding plays a critical role in improving growth performances, feed conversion ratio, gut health and immunity in poultry. It is the novel way to achieve optimum broiler performance by minimizing feed costs and thereby pressure on food ecosystem (Bhanja and Mandal 2005). It is the administration of exogenous nutrients into the amnion of the late-term avian embryo only (Uni and Ferket 2003). The carbohydrate free medium consisting of finite proportion of energy helps in development of avian embryo i.e. closed nutrition and nutrients for growth and development invested by the broiler breeder hen to support embryonic growth and hatching (Burley and Vadehra 1989). Because of the oral consumption of amniotic fluid (mainly water as well as albumen protein) by the avian embryo prior to the pipping of air cell around 18d of incubation in chicken, in ovo feeding can improve the energy status and gut development of the perinatal chick by supplementing the amnion with nutrients (Moran 2007). Early nutritional feeding programme like in ovo feeding will stimulate early gut development leading to better absorption and quality chicks. The embryonic developmental period as well as the first week after hatching represents a larger proportion (45\%) of the whole life span in fast growing broilers. Thus, prehatch as well as the transitional post-hatch period must be achieved efficiently for survival and subsequent growth of fast-growing broilers. Improvement in initial hatch weight and immunity reduces number of mortality and morbidity which in turn reduces production of bio-waste. Therefore, different nutrients need to be examined for accelerating hatchability, hatch weight and immunity using in ovo technology. Both the amino acids (arginine as well as tryptophan) have beneficial effect on avian systems of immune response (Nayak et al. 2017; Odutaya et al. 2020). Arginine is one of the most 
versatile amino acids in the animal cells (Wu and Morris 1998). Ball et al. (2007) studied that, birds have the absolute requirement of arginine which is due to lack of endogenous arginine synthesis and high protein deposition. Arginine promotes the faster growth of broiler line being a secretagogue increasing the release of growth hormone (Edmonds and Baker 1987). The candidate nutrient tryptophan has great impact through in ovo feeding which boosts body weights, immune system and overall performance of chick (Nayak et al. 2018). However, there is no finding regarding the regulatory effects of tryptophan and the combination of arginine and tryptophan through in ovo feeding method. Hence the study was undertaken to evaluate the potential effects of in ovo arginine and tryptophan feeding on hatchability, production performances and immune response in broilers.

\section{Materials And Methods}

In ovo injection

Total 700 fertile broiler eggs were obtained from $34 \mathrm{wk}$ old Cobb 400 breeders and incubated in forced draft automatic chicken incubator. Infertile eggs were discarded after candling on 18d of incubation and fertile eggs were randomly assigned to each treatment. The surface of the egg shell was disinfected with ethanol $(99.90 \%)$ and then a pin point hole was created just under the air cell opposite to the head spot by a sterile egg shell driller. Five treatment groups viz., non-injected control, injected control $(0.5 \mathrm{ml}$ of $0.9 \%$ normal saline), arginine $(0.5 \mathrm{ml}$ of $0.5 \%$ arginine), tryptophan $(0.5 \mathrm{ml}$ of $0.5 \%$ tryptophan) and combination $(0.25 \mathrm{ml}$ of $0.5 \%$ each of arginine and tryptophan) were prepared. The treatment solutions were warmed up to room temperature and injected into the amnion of $18 \mathrm{~d}$ old embryo using $25 \mathrm{~mm}$ needle (Uni and Ferket 2003). The pinhole site was immediately sealed with sterile paraffin wax and eggs were kept in the incubator. On 19d of incubation, the eggs were transferred to a hatcher and placed in well-marked pedigree hatching boxes.

\section{Housing and management practices}

Total 540 chicks (108 birds per treatment with 6 replicates 18 in each replicate) were randomly selected and per cent hatchability was calculated for each treatment. Individual chick weight was recorded at hatching. Chicks hatched from various treatment groups were distributed randomly and placed in experimental brooding cages in a well-lit ventilated open sided house. On $15 \mathrm{~d}$ chicks were transferred to growing cages and reared up to $35 \mathrm{~d}$. Ad libitum feed and water was provided with similar nutrient composition based on Vencobb standard guide. Throughout the experiment standard management practices were followed in test and control groups.

\section{Hatchability and production performances}

The hatchability percentage calculated based on fertile egg set basis. Each chick was individually weighed at farm after transporting from hatchery and the transit loss was calculated based on the hatch weight and placement weight. Body weight gain was estimated by weighing individual birds at weekly interval up to $35 \mathrm{~d}$. The per cent livability was worked out based on mortality of birds. 


\section{Organ indices}

At the end of 35d, 12 birds close to mean body weight from each replicate were randomly selected for carcass characteristics. Live, eviscerated, giblets and ready-to-cook weights were measured and given in percentage based on live weight. Cut-up parts viz., breast, back, thigh, drumstick, neck and wing were individually weighed and figured in percentage based on eviscerated weight.

\section{Glycogen status}

Six chicks of $4 \mathrm{~d}$ and $21 \mathrm{~d}$ old age from each experimental treatment were randomly selected. The weight of the chick was determined and liver tissue was collected from chicks and stored at $-20^{\circ} \mathrm{C}$ for glycogen estimation. Glycogen content in the liver sample was estimated by Anthrone method (Seifter et al. 1949).

\section{Intestinal morphometry}

Twelve birds were randomly used on the 4 and $35 \mathrm{~d}$ to study the intestinal length and histomorphometry. The collected intestines were hand pressed to remove the feed ingredients and then flushed with PBS $\left(0.1 \mathrm{M}, \mathrm{p}^{\mathrm{H}} 7.4\right)$ to remove all the remaining contents. Approximately two cms from each segment of duodenum, jejunum and ileum were cut, washed with PBS $\left(0.1 \mathrm{M}, \mathrm{p}^{\mathrm{H}} 7.4\right)$ and placed separately in a $10 \%$ formalin solution for further processing. Measurements such as villus height from tip of villi to crypt, mid villus width, crypt depth from the base of villi to the submucosae, ratio of villus height to crypt depth were taken.

\section{Immunity parameter}

Immunity parameters viz., immune organ weight, gene expression, Haemagglutination (HA) and Haemagglutination inhibition $(\mathrm{HI})$ titre were studied. Six birds from each replicate were sacrificed on 4, 21 and 35d. Thymus and splenocytes were collected for expression of immunity related IFN-y and IL-8 genes. RNA was extracted from cells of spleen and intestine using TRIZOL® reagent as per the manufacture's instruction with minor modifications at RNA pellet washing step wherein the pellet was washed twice with $75 \%$ ethanol by centrifuging at $7500 \mathrm{~g}$ for 5 mins and RNA pellet was air dried for 5 mins. The RNA pellet was redissolved in DNase-RNase free water. The concentration of RNA was estimated at $260 / 280 A^{\circ}$ in a spectrophotometer (Biophotometer Plus, Eppendorf). The synthesis of cDNA was carried out using Fermentas cDNA synthesis kit. For each gene, $10 \mu \mathrm{l}$ cDNA was synthesized using negative sense gene specific primers. After CDNA synthesis, $1 \mu$ of cDNA from respective genes was pooled and serially diluted, quantified and used for putting standard curve in relative quantitative PCR assay. A concentration of $\sim 200 \mathrm{ng} / \mu \mathrm{l}$ was used for real time PCR. The primers (Table 1 ) for the amplification and quantification of cellular/cytokine genes by quantitative real-time PCR was carried out with minor modifications as prescribed by Li et al. (2007) for $\beta$-actin, IFN- $\gamma$ and IL-8 genes. The annealing temperature for IFN- $\gamma$ was modified to $58^{\circ} \mathrm{C}$ (Laurent et al. 2001) in a real-time thermocycler (Mastercycler® Eprealplex, model\#22331, Eppendorf, Germany). The standard curve method was used for expression of cellular/cytokine genes. 
The HA and HI was performed for New Castle disease virus for which two milliliters of blood was collected from six birds from each treatment on the 4, 21 and $35 \mathrm{~d}$. The blood was kept undisturbed for separation of serum.

\section{Statistical Analysis}

Data was analyzed based on ANOVA using Version 20.0 of SPSS software. Differences between treatments were detected by the Duncan's multiple range tests following ANOVA, and values were considered statistically different at $\mathrm{P}<0.05$.

\section{Results And Discussion Hatchability}

The effect of in ovo feeding of arginine, tryptophan and their combination on the $18 \mathrm{~d}$ of incubation through amnion in broiler breeder chicken egg on hatchability, hatch weight and chick to egg weight ratio is presented (Table 2). In ovo feeding with arginine, tryptophan and their combination had no significant effect on hatchability. However, a numerically higher percentage of hatchability was observed in the in ovo fed arginine and tryptophan ( $96.42 \%$ and $95.71 \%)$ groups as compared to positive and negative control groups ( $95.71 \%$ and $94.28 \%$ ), respectively. Similar findings were observed by Ohta et al. (2004), Bhanja and Mandal (2005), Bhanja et al. (2012), Chamani et al. (2012) and Shafey et al. (2014). However, Foye et al. (2006) had recorded better hatchability at $0.7 \%$ arginine compared to $0.2 \%$ arginine in ovo fed turkey poults. In ovo feeding with arginine significantly $(P<0.01)$ improved hatch weight $(45.18 \pm 0.24)$ and was comparable with injected control $(44.50 \pm 0.26)$, while the effect of tryptophan was comparable with non-injected control. The per cent difference in hatch weight between the treatments relative to arginine is furnished in graph (Figure 1) which had the best hatchability and was taken as $100 \%$. The hatch weight of chicks showed a highly significant $(\mathrm{P} \leq 0.01)$ difference between treatments. Arginine fed groups had highest hatch weight as compared to injected control groups. This agreed with findings of Al-Murrani (1982), Ohta et al. (2004), Bhanja and Mandal (2005), Foye et al. (2006), Kulandaivel (2007) and Shafey et al. (2014); but Ohta et al. (1999 and 2001) and Ohta and Kid (2001) found no significant difference in hatch weight due to in ovo amino acids feeding. Chick to egg weight ratio also showed significant $(P<0.05)$ difference ranging from $72.01 \pm 0.49$ to $74.62 \pm 0.39$. In ovo feeding with arginine significantly improved egg to chick weight ratio than other in ovo fed groups and un-injected and injected control. Chick to egg weight ratio also followed a similar trend as hatch weight. This effect was also noticed by Ohta et al. (1999, 2001 and 2004), Bhanja and Mandal (2005) and Shafey et al. (2014). Whereas Ohta et al. (2001 and 2004) did not find significant difference in hatching body weight relative to egg weight.

\section{Placement weight and transit weight loss}

Effect of in ovo feeding of arginine, tryptophan and their combination on placement weight and transit weight loss is presented (Table 2). Body weight of chicks (first day at farm) specified as placement weight showed a highly significant difference between treatments, with arginine in ovo fed chicks having 
significant $(P<0.01)$ higher body weight. All other treatment had comparatively similar body weight; however, lowest placement weight was observed in the combination group and non-injected control and those were comparable. No significant difference was observed between treatments in transit weight loss however, numerically arginine fed groups had lower transit weight loss compared to all other treatment groups. Placement weight was significantly higher in arginine in ovo fed group and no relevant literature was available for comparison except Coles et al. (2001) who observed no significant difference in treatment with respect to placement weight. This could be related to transit weight loss although no significant difference was observed in transit weight loss in this study. It has been noticed that amino acid fed groups had numerically lower transit loss compared to others. Kanagaraju (2014) had observed significantly lower transit weight loss in lysine and threonine fed groups, which averaged to $4.99 \%$ as compared to control.

\section{Effect Of In Ovo Feeding On Production Performance Body weight gain}

Mean body weight gain of broilers (g) as influenced by in ovo feeding of arginine, tryptophan and their combination at day old and at weekly intervals up to five weeks of age has been presented (Table 3). The body weight gain from 0-3, 3-5 and 0-5 weeks shown in graphical presentation (Figure 2). The results indicated a highly significant difference $(P<0.01)$ between treatments at 1 st wk and significant difference $(P<0.05)$ in 2 nd and 3rd wk. However, the weight advantage was sustained up to $21 \mathrm{~d}$ only between treatments due to in ovo feeding. In ovo feeding with arginine produced significantly $(P<0.01)$ heavier birds in 1st, 2nd and 3rd wk continuously as compared to injected control and also with the combination group during the 2nd wk alone. In ovo tryptophan added group and the negative control (un-injected control) had lower body weight from 1st to 3rd wk continuously. Birds fed with in ovo arginine had significantly $(P<0.05)$ higher body weight gain in $2 n d$ wk and highly significant $(P<0.01)$ higher gain in 3rd wk, and the same result was obtained in 2 nd wk among combination group.

The highly significant $(P \leq 0.01)$ and a significant difference $(P \leq 0.05)$ in body weight were observed in 1 st wk and later in 2nd and 3rd wk of age respectively. Throughout the three wk of study, arginine injected in ovo group gave the best body weight. This increase in body weight was sustained up to 3rd wk. Among the literature reviewed two types of results were noticed of which work done by Coles et al. (2001), Bhanja and Mandal (2005), Foye et al. (2006), Abdukalykova et al. (2008), Chamani et al. (2012), Kanagaraju (2014) and Odutaya et al. (2020) had observed that the amino acids had improved body weight only up to 1st and 2nd wk; while Al-Murrani (1982) and Bhanja et al. (2012) working on broilers and Al-Daraji et al. (2012), who studied on quails, observed increased body weight in amino acid fed birds right up to the end of the study mainly 56 and $42 \mathrm{~d}$ of age respectively. Our result seems to fall between these two categories, where body weight increased up to $21 \mathrm{~d}$ and later the effect of in ovo feeding with arginine, waned into insignificance. Arginine in ovo fed groups showed best body weight gain comprising significant $(P<0.05)$ result during $2 n d$ wk and highly significant $(P<0.01)$ during $3 r d$ wk; and it is in 
agreement with the findings of Bhanja et al. (2012) and Shafey et al. (2014). Shafey et al. (2014) had provided three groups of amino acid combination and they observed that the combination with arginine, glutamine, glycine and proline gave the best result and they attributed this increased body weight gain to arginine. It could be assumed that in ovo treatment of arginine had probably supported chick weight up to $21 \mathrm{~d}$ of age as a result of increasing amino acids which could have enhanced protein synthesis after hatching.

\section{Feed consumption}

Feed consumption in broilers was not influenced by in ovo feeding and had no significant difference between treatments; however, a numerically better feed consumption was observed in in ovo amino acid groups. There was no significant difference in feed efficiency, but it has been noticed that cumulative feed intake was numerically higher in tryptophan and in the combination group. Bhanja et al. (2004 and 2012), Saki et al. (2013) and Al-Daraji et al. (2012) found no significant treatment effect on feed intake with regards to amino acid in ovo feeding but they observed difference with respect to feed conversion ratio, while Bhanja and Mandal (2005), Gaafar et al. (2013), Shafey et al. (2014), Eslami et al. (2014) and Kanagaraju (2014) observed similar results with no significant difference for feed efficiency. However, the results of high feed intake were observed in the group of birds fed with tryptophan. Emadi et al. (2011) had found a complementary effect with increased feed intake due to the precursor function of tryptophan for neurotransmitter serotonin that found in brain increases feed intake (Tackman et al. 1990; Muller and Martin 1992; Shea-Moore et al. 1996; Peganova and Eder 2003).

\section{Livability}

The livability up to five weeks of age was lowest in control, while in the amino acid in ovo fed groups; it ranged from 99.07 to $100 \%$. No significant difference was observed in livability percentage between all the treatment groups. However, it may be noted that arginine and tryptophan in ovo fed groups had no mortality. Uni and Ferket (2004) have stated in ovo feeding of nutrients improved livability and reduce mortality at any age period. Similar report was obtained by Dos Santos et al. (2010), Saki et al. (2013) and Kanagaraju (2014).

\section{Carcass characteristics and cut-up parts of broilers}

The effect of in ovo arginine and tryptophan nutrition on carcass characteristics and cut-up parts of broilers (Table 4 and Table 5) and the per cent breast with relation to eviscerated carcass yield (Figure 3 ) are presented. A highly significant $(P<0.01)$ difference was observed between treatment groups for eviscerated and ready-to-cook weight. Arginine fed group stood out as significantly $(P<0.01)$ the best, both in eviscerated and ready-to-cook weights. There was no significant difference between treatments in cut up parts except breast yield where the treatment groups differ significantly $(P<0.05)$. All the in ovo fed groups gave significantly $(P<0.01)$ higher breast yield with tryptophan and combination group. A clear increase in per cent yield of breast relative to carcass yield could be observed in tryptophan fed followed by the combination group. 
Many literatures have observed better carcass yield in broilers towards general amino acid in ovo feeding rather than specifically with arginine and tryptophan (Bhanja et al. 2004; Hajihosaini and Mottaghitalab 2004; Kanagaraju 2014). However, a more specific study with in ovo nutrition by Al-Daraji (2012) on Japanese quails, agreed with our findings where arginine had improved carcass weight. No literature could be traced for tryptophan in ovo feeding with regards to carcass weight in broiler. The tryptophan and combination group gave higher breast yield than the arginine fed groups which is agree with Foye et al. (2006).

\section{Glycogen status}

A highly significant difference $(\mathrm{P}<0.01)$ was observed on 4 th day and 21 st day between treatments. In ovo fed arginine group had significantly higher $(P<0.01)$ glycogen level which was comparable with combination and injected control, but differed significantly from tryptophan and un-injected control (Table 6). Foye et al. (2006) observed in ovo fed with arginine, $\beta$-hydroxy- $\beta$-methylbutyrate (HMB) and $\beta$ hydroxy- $\beta$-methylbutyrate (HMB) + Arginine (ARG) in poults had increased total hepatic glycogen content at day of hatch in comparison to controls. This was explained by the fact that avian embryo develops in virtually carbohydrate-free environment and must rely upon gluconeogenesis for the production of glucose, the primary fuel for growth and development. In ovo fed poults had a higher gluconeogenic activity at hatch than the control as indicated by enhanced hepatic glucose-6-phosphatase $\left(\mathrm{G}_{6} \mathrm{P}\right)$ activity. Hence, in ovo feeding may increase the late term embryo's capacity to convert gluconeogenic precursors (amino acids and protein) into glucose, for storage in liver and muscle as glycogen and may directly enhance hepatic glycogen accretion.

\section{Intestinal morphometry}

The results indicated that there existed no significant differences between different treatments for the parameters like length $(\mathrm{cm})$ of intestine, duodenum, jejunum and ileum during 35th day, but significant $(\mathrm{P}<0.05)$ difference was observed among treatments on 4th day. In ovo fed combination group presented highest total intestinal length $(69.25 \pm 1.59)$ followed by tryptophan $(66.19 \pm 2.06)$ and arginine (64.45 22.49). Uni and Ferket (2004) observed at day one the gastro intestinal tract of in ovo fed chick were functionally at a similar stage of development as a conventional two-day old chick offered feed immediately after hatch. Dror et al. (1997) had also observed maximal relative size of digestive organs in chicks occurs at 3-7 day of age. This agreed with our findings where the increase in intestinal length was observed during 4th day and not later. The absorption of tryptophan, arginine and their combination had increased intestinal length most probably due to increase in ileum length. There was significant $(P<0.05)$ difference in villi height in duodenum and ileum on 4th day; whereas on 35th day a highly significant $(P<0.01)$ difference was observed in villus height and mid villus width in duodenum and jejunum; but not in ileum (Table 7 and Table 8). Murakami et al. (2012) had provided dietary arginine to broilers and observed duodenal villus: crypt ratio increased in the first week. The same was observed in the in ovo fed arginine group on 4th day where the villi height increased and crypt depth had decreased but the villus: crypt ratio was not significant. Sklan (2001) who first worked on early chick feeding had stated the ability of intestinal tissue to digest and absorb nutrients had caused an increase in villus growth. 


\section{Immune response}

There was no significant difference between treatments for thymus weight; numerically the combination group $(0.113 \pm 0.005)$ gave better weight followed by tryptophan $(0.095 \pm 0.004)$ and arginine $(0.090 \pm 0.004)$ group. This observation was in line with the findings of Bhanja et al. (2004) who have reported that in ovo feeding of amino acids have no significant effects on weight of immune organs. The thymus is very sensitive to periods of food deprivation, which caused a rapid decline in CD4+ T cells resulting in lower IgG production. The CD4+ cells act as the source for IL-6, a pro-inflammatory cytokine, which induces the final maturation of B cells into antibody-secreting plasma cells causing the proliferation and differentiation of immunoglobins. Kidd et al. (2001 and 2002) also reported that commercial broilers fed arginine levels above NRC (1994) recommendations did not increase the weight of immune organs. Abdukalykova and Ruiz-Feria (2006) and Kwak et al. (1999) fed broilers with graded level of arginine and found no significant difference in thymus weight. It may be that arginine supplementation resulted in significant dose related increase in immune organs. In broilers, growth of the thymus was affected to a great extent by arginine deficiency (Kwak et al. 1999).

The expression profile of IL-8 gene did not change in arginine and combination groups. IL-8 did not express itself in all the amino acid treatment groups except tryptophan to a certain extent. With regards to IFN- $\gamma$ gene, combination group showed better immune response than all other treatments. In ovo fed arginine was found to be more immune-competent than tryptophan. The relative expression of cell mediated immunity related genes (IL-8 and IFN- $\gamma$ ) have been presented (Figure 4).

The IL-8 gene is pro inflammatory and responsive for influx of heterophils and initiation of wound healing cascade (Henderson et al. 1999). The static expression of IL8 gene justifies the fact that F-strain of RDVF vaccine is lentogenic and do not produce inflammation. IL-8 gene was expressed more in control followed by tryptophan group. With regards to IFN- $\gamma$ gene, combination group showed better immune-response than all other treatments. In ovo fed arginine was found to be more immunocompetent than in ovo fed tryptophan which is in agreement with Emadi et al. (2011) who observed increased level of IFN-y in serum when chicks challenged with infectious bursal disease are fed with different level of dietary tryptophan but, Bhanja et al. (2014) observed no difference in the expression of IFN- $y$ gene in amino acid (lysine and arginine) injected chicks when compared to un-injected control group. In this study it is concluded that the combination group of arginine and tryptophan enhanced the expression of immune genes in broiler chicken.

Effect of in ovo feeding of arginine, tryptophan and their combination on graphical representation of $\mathrm{HI}$ titre against ND virus is presented (Figure 5). In $\mathrm{HI}$ assay high antibody titre was found on $4 \mathrm{~d}$ in all the treatments especially in arginine in ovo fed group which showed significantly $(P<0.05)$ higher antibody titre than other treatments, later it subsided after vaccination with RDVF on 10d. This may be due to the presence of higher concentration of maternal antibodies in the serum samples, which neutralized the vaccinated antigen and this exists up to $35 \mathrm{~d}$. This shows that there is no free antigen to induce humoral mediated immunity ( $\mathrm{HMI})$ which leads to no increase in antibody titre after vaccination. So, it is advisable 
to wait for complete disappearance of maternal antibodies prior to vaccination. The positive effect of arginine on T-cell production, proliferation and maturation owes to its immunoregulatory effects (Daly et al. 1990; Ochoa et al. 2001). It also stimulates the proliferation of CD4+ and CD8+ cells (Abdukalykova et al., 2008). Mellor and Munn (2003) reported that tryptophan enhances T-cell response during infection and stimulates T-cell proliferation.

\section{Conclusion}

Nutritional and metabolic exposure of embryo and chick may have long term programming effects into maturity. In ovo feeding of arginine had improved chick performance, body weight and body weight gain and also provided the bird with higher immunomodulation although body weight and body weight gain were not sustained beyond $21 \mathrm{~d}$. Tryptophan on the other hand had not shown any significant effect with respect to hatch weight and body weight. However, it has effect on immunomodulation and increase in breast muscle fibre that improved breast per cent with relation to eviscerated carcass weight.

\section{Declarations}

\section{Author contributions}

Nibedita Nayak: Investigation, in ovo injection, scientific intervention in field trial, production data recording, biochemical and immunological reactions, carcass study, writing original draft, review and editing. R. Asha Rajini: Concept of work, project administration, draft review and editing. Amiya Ranjan Sahu: In ovo injection, carcass study, statistical data analysis and draft preparation. J. John Kirubaharan: Immunological study, gene expression and analysis, and draft editing. S.

Ezhilvalavan: Resources, hatchery management, in ovo injection and draft editing.

\section{Code availability}

Not applicable.

\section{Data availability}

All the data are available from the sources cited in the "Materials and methods" and from the authors upon request.

\section{Declarations Conflict of interest}

The authors declare no competing interests.

\section{Consent to participate}

The corresponding author is willing to participate in reviewing the manuscripts submitted to this journal.

\section{Consent for publication}


The manuscript has not been submitted to any other journal. The publication of the manuscript in this journal will be highly appreciated.

\section{Compliance with ethical standards}

The samplings from experimental birds were done in accordance with the ethical standards approved by Institute Animal Ethical Committee.

\section{Acknowledgements}

Authors are thankful to the Dean, Madras Veterinary College, TANUVAS, Chennai, India for providing necessary facilities and funding support to carry out the research work.

\section{References}

1. Abdukalykova, S.T. and Ruiz-Feria, C.A. 2006. Arginine and vitamin E improve the cellular and humoral immune response of broiler chickens. International Journal of Poultry Science 5: 121-127.

2. Abdukalykova, S.T., Zhao, X. and Ruiz-Feria, C.A. 2008. Arginine and vitamin E modulate the subpopulations of T lymphocytes in broiler chickens. Poultry Science 5: 121-127.

3. Al-Daraji, J.H., Al-Mashadani, A.A., Al-Hayani, W.K., Al-Hassani, A.S. and Mirza, H.A. 2012. Effect of in ovo injection with L-arginine on productive and physiological traits of Japanese quail. South African Journal of Animal Science 42: 140-145.

4. Al-Murrani, W.K. 1982. Effect of injecting amino acids into the egg on embryonic and subsequent growth in the domestic fowl. British Poultry Science 23: 171-174.

5. Ball, R.O., Urschel, K.L. and Pencharz, P.B. 2007. Nutritional consequences of interspecies differences in arginine and lysine metabolism. Journal of Nutrition 137: 1626-1641.

6. Bhanja, S.K. and Mandal, A.B. 2005. Effect of in ovo injection of critical amino acids on pre- and post-hatch growth, immunocompetence and development of digestive organs in broiler chickens. Asian-Australasian Journal of Animal Science 18: 524-531.

7. Bhanja, S.K., Mandal, A.B. and Goswami, T.K. 2004. Effect of in ovo injection of amino acids on growth, immune response, development of digestive organs and carcass yield of broiler. Indian Journal of Poultry Science 39: 212-18.

8. Bhanja, S.K., Mandal, A.B., Agarwal, S.K. and Majumdar, S. 2012. Modulation of post-hatch growth and immunocompetence through in ovo injection of limiting amino acids in broiler chickens. Indian Journal of Animal Sciences 82: 993-998.

9. Bhanja, S.K., Sudhagar, M., Pandey, N., Goel, A., Mehra, M., Agarwal, S.K. and Mandal, A. 2014. Differential expression of growth and immunity related genes influenced by in ovo supplementation of amino acids in broiler chickens. Czech Journal of Animal Science 59: 399-408.

10. Burley, R.W. and Vadehra, D.V. 1989. The Avian Egg Chemistry and Biology. New York, USA: WileyInterscience 1989: 132-139. 
11. Chamani, M., Tasharrofi, Sh., Forudi, F., Sadeghi, A.A. and Aminafshar, M. 2012. Evaluation the Effects of in ovo injection of different nutrients on hatch percentage, performance and carcass parameters of broilers. Annals of Biological Research 3: 3771-3776.

12. Coles, B.A., Croom, J., Daniel, L.R., Christensen, V.I. and Eisen, E.J. 2001. In ovo peptide YY administration improves body weight at hatch and day 3 in turkey poults. Journal of Applied Poultry Research 10: 380-384.

13. Daly, J., Reynolds, J., Sigal, R.K., Shou, J. and Liberman, M.D. 1990. Effect of dietary protein and amino acids on immune function. Critical Care Medicine 18: 86-93.

14. Dos Santos, T.T., Corzo, A., Kidd, M.T., McDaniel, C.D., Torres Filho, R.A. and Araujo, L.F. 2010. Influence of in ovo inoculation with various nutrients and egg size on broiler performance. Journal of Applied Poultry Research 19: 1-12.

15. Dror, Y., Nir, I. and Nitsan, Z. 1997. The relative growth of internal organs in light and heavy breeders. British Poultry Science 18: 493-496.

16. Edmonds, M.S. and Baker, D.H. 1987. Comparative effects of individual amino acid excesses when added to a corn-soybean meal diet: effects on growth and dietary choice in the chick. Journal of Animal Science 65: 699-705.

17. Emadi, M., Jahanshiri, F., Kaveh, K., Hair-Bejo, M., Ideris, A. and Alimon, A.R. 2011. Nutrition and immunity: the effects of the combination of arginine and tryptophan on growth performance, serum parameters and immune response in broiler chickens challenged with infectious bursal disease vaccine. Avian Pathology 40: 63-72.

18. Eslami, M., Salarmoini, M. and Tasharrofi, S. 2014. Effects of in ovo injection of different nutrients on the hatchability and growth performance in broilers. Journal of Livestock Science and Technologies 2: 1-7.

19. Foye, O.T., Uni, Z., McMurtry, J.P. and Ferket, R.P. 2006. The effects of amniotic nutrients administration, in ovo feeding of arginine and/or $\beta$-hydroxy $\beta$-methylbutyrate (HMB) on insulin-like growth factors, energy metabolism and growth in turkey poults. International Journal of Poultry Science 5: 309-317.

20. Gaafar, K.M., Selim, S.A. and El-ballal, S.S. 2013. Effect of in ovo administration with two levels of amino acids mixture on the performance of Muscovy ducks. Emirates Journal of Food and Agriculture 25: 58-65.

21. Hajihosaini, M. and Mottaghitalab, M. 2004. Effect of amino acid injection in broiler breeder eggs on hatchability and growth of hatched chicken. Journal of Agricultural Science 1: 23-32.

22. Henderson, S.C., Bounous, D.I. and Lee, M.D. 1999. Early events in the pathogenesis of avian salmonellosis. Infection and Immunity 67: 3580-3586.

23. Kanagaraju, P. 2014. Effect of in ovo feeding and early chick nutritional supplement on growth performance of hybrid broiler chicken. Ph.D thesis submitted to TANUVAS, Chennai.

24. Kidd, M., Peebles, E.D., Whitmarsh, S.K., Yeatman, J.B. and Wideman, R.F. 2001. Growth and immunity of broiler chickens as affected by dietary arginine. Poultry Science 80: 1535-1542. 
25. Kidd, M.T., Thaxton, J.P., Yeatman, J.B., Barber, S.J. and Virden, W.S. 2002. Arginine responses in broilers: Live performance. Poultry Science 80 (1): 114.

26. Kulandaivel, K. 2007. Developing strategic supplementation to enhance neonatal growth in broilers. M.V.Sc thesis submitted to TANUVAS, Chennai.

27. Kwak, H., Austic, R.E. and Dietert, R.R. 1999. Influence of dietary arginine concentration on lymphoid organ growth in chickens. Poultry Science 78: 1536-1541.

28. Laurent, F., Mancassola, R., Lacroix, S., Menezes, R. and Naciri, M. 2001. Analysis of chicken mucosal immune respoinse to Eimeria tenella and Eimeria maxima infection by quantitative reverse transcription PCR. Infection and Immunity 69: 2527-2534.

29. Li, Y.P., Handberg, K.J., Madson J.H.R., Zhang, M.F. and Jorgenten, P.H. 2007. Transcriptional profile of chicken embryo cell cultures following infection with infectious bursal disease virus. Archives of Virology 152: 463-478.

30. Mellor, A. and Munn, D. 2003. Tryptophan catabolism and regulation of adaptive immunity. Journal of Immunology 170: 5809-5813.

31. Moran Jr, E.T. 2007. Nutrition of the developing embryo and hatchling. Poultry Science 86 (5): 10431049.

32. Mullen, B.J. and Martin, R.J. 1992. The effect of dietary fat on diet selection may involve central serotonin. American Journal of Physiology 263: 559-563.

33. Murakami, A.E., Fernandes, J.I.M., Hernandes, L. and Santos, T.C. 2012. Effects of starter diet supplementation with arginine on broiler production performance and on small intestine morphometry. Pesquisa Veterinaria Brasileira 3: 259-266.

34. Nayak, N., Rajini, R.A., Ezhilvalavan, S., Sahu, A.R. and Kirubaharan, J.J. 2017. Comparative effect of arginine and/or tryptophan in ovo feeding on hatchability percentage, growth performance and economic importance of commercial broiler. Indian Journal of Animal Sciences 87 (2): 153-158.

35. Nayak, N., Rajini, R. A., Kirubaharan, J. J., Ezhilvalavan, S. and Sahu, A. R. 2018. Effect of in ovo feeding of tryptophan on post-hatch production performance and immune response in commercial broilers. Animal Nutrition and Feed Technology 18: 355-366.

36. National Research Council 1994. Nutrient requirements of poultry, 9th Ed. Natl Acad Sci Washington, DC.

37. Ochoa, J.B., Strange, J., Kearney, P., Gellin, G., Endean, E. and Fitzpatrick, E. 2001. Effects of arginine on the proliferation of T-lymphocyte subpopulations. Journal of Parenteral and Enteral Nutrition 25: 23-29.

38. Odutayo, O.J., Sogunle, O.M., Adeyemi, O.A. and Sonibare, A.O. 2020. Influence of in ovo arginine feeding on hatching traits and post-hatch performance of FUNAAB-Alpha chickens in two housing types. Tropical Animal Health and Production 52 (5): 2349-2357.

39. Ohta, Y., Tsushima, N., Koide, K., Kidd, M.T. and Ishibashi, T. 1999. Effect of amino acid injection in broiler breeder eggs on embryonic growth and hatchability of chicks. Poultry Science 78: 1493-1498. 
40. Ohta, Y. and Kidd, M. 2001. Optimum site for in ovo amino acid injection in broiler breeder eggs. Poultry Science 80: 1425-1429.

41. Ohta, Y., Kidd, M.T. and Shibashi, T. 2001. Embryo growth and amino acid concentration profiles of broiler breeder eggs, embryos, and chicks after in ovo administration of amino acids. Poultry Science 80: $1430-1436$.

42. Ohta, Y., Yoshida, T. and Tsushima, N. 2004. Comparison between broilers and layers for growth and protein use by embryos. Poultry Science 83: 783-787.

43. Peganova, S. and Eder, K. 2003. Interactions of various supplies of isoleucin, valine, leucine and tryptophan on the performance of laying hens. Poultry Science 82: 100-105.

44. Saki, A., Haghighat, M. and Khajali, F. 2013. Supplemental arginine administered in ovo or in the feed reduces the susceptibility of broilers to pulmonary hypertension syndrome. British Poultry Science 54: 575-580.

45. Seifter, S., Dayton, B.S., Novic, B. and Muntwyler, E. 1949. The estimation of glycogen with the anthrone reagent. Archives of Biochemistry 25: 191-200.

46. Shafey, T.M., Mahmoud, A.H., Alsobayel, A.A. and Abouheif, M.A. 2014. Effects of in ovo administration of amino acids on hatchability and performance of meat chickens. South African Journal of Animal Science 44: 123-130.

47. Shea-Moore, M.M., Thomas, O.P. and Mench, J.A. 1996. Decreases in aggression in tryptophansupplemented broiler breeder males are not due to increases in blood niacin levels. Poultry Science 75: $370-374$.

48. Sklan, D. 2001. Development of the digestive tract of poultry. World's Poultry Science Journal 57: 415-428.

49. Tackman, J., Tews, J.K. and Harper, A.E. 1990. Dietary disproportions of amino acids in the rat: effects on food intake, plasma and brain amino acids and brain serotonin. Journal of Nutrition 120: 521-533.

50. Uni, Z. and Ferket, P.R. 2003. Enhancement of development of oviparous species by in ovo feeding. US Patent 6, 592, 878. North Carolina State University, Raleigh, NC; and Yissum Research Development Company of the Hebrew University of Jerusalem, Jerusalem (Israel), assignees.

51. Uni, Z. and Ferket, P.R. 2004. Methods for early nutrition and their potential. World's Poultry Science Journal 60: 101-111.

52. Wu, G. and Morris Jr, S.M. 1998. Arginine metabolism: Nitric oxide and beyond. Biochemistry Journal 336: 1-17.

\section{Tables}

Table 1 Details of primer sequences used in qRT-PCR. 


\begin{tabular}{|c|c|c|c|}
\hline \multirow[t]{2}{*}{ Gene } & Primer sequences ( $\left.5^{\prime}-3^{\prime}\right)$ & Annealing & Product \\
\hline & (F- Forward and R- Reverse) & Temperature $\left({ }^{\circ} \mathrm{C}\right)$ & Size $(b p)$ \\
\hline \multirow[t]{2}{*}{$\beta$-actin } & F- GAGAAATTGTGCGTGACATCA & 58 & 152 \\
\hline & R- CCTGAACCTCTCATTGCCA & & \\
\hline \multirow[t]{2}{*}{ IFN-Y } & F- GAACGACTTGAGAATCCAGC & 58 & 146 \\
\hline & R- GAGCACAGGAGGTCATAAGA & & \\
\hline \multirow[t]{2}{*}{ IL-8 } & F- GCTCTGTCGCAAGGTAGGAC & 58 & 184 \\
\hline & R- CCAGCACACCTCTCTTCCA & & \\
\hline
\end{tabular}

Table 2 Effect of in ovo feeding of arginine, tryptophan and their combination on hatchability, hatch weight, chick/egg weight ratio, placement weight and transit weight loss (Mean \pm S.E).

\begin{tabular}{|c|c|c|c|c|c|}
\hline \multirow[t]{2}{*}{ Variables (g) } & \multicolumn{5}{|l|}{ Treatments } \\
\hline & Control & $\begin{array}{l}\text { Injected } \\
\text { control }\end{array}$ & $\begin{array}{l}\text { Arginine } \\
\text { (Arg) }\end{array}$ & $\begin{array}{l}\text { Tryptophan } \\
\text { (Trp) }\end{array}$ & $\begin{array}{l}\text { Combination } \\
\text { (Arg+Trp) }\end{array}$ \\
\hline $\begin{array}{l}\text { Hatchability }(\%)^{N S} \\
(n=140)\end{array}$ & 95.71 & 94.28 & 96.42 & 95.71 & 93.57 \\
\hline $\begin{array}{l}\text { Hatch egg } \\
\text { weight }^{N S} \\
(n=140)\end{array}$ & $60.54 \pm 0.004$ & $60.53 \pm 0.011$ & $60.55 \pm 0.004$ & $60.54 \pm 0.008$ & $60.53 \pm 0.004$ \\
\hline $\begin{array}{l}\text { Hatch weight** } \\
(n=108)\end{array}$ & $43.96^{b c} \pm 0.29$ & $44.50^{a b} \pm 0.26$ & $45.18^{a} \pm 0.24$ & $44.35^{\mathrm{bc}} \pm 0.22$ & $43.59^{c} \pm 0.30$ \\
\hline $\begin{array}{l}\text { Chick/Egg weight } \\
\text { ratio** } \\
(n=108)\end{array}$ & $72.6^{\mathrm{bc}} \pm 0.48$ & $73.5^{\mathrm{ab}} \pm 0.43$ & $74.62^{\mathrm{a}} \pm 0.39$ & $73.25^{\mathrm{bc}} \pm 0.37$ & $72.0^{c} \pm 0.49$ \\
\hline 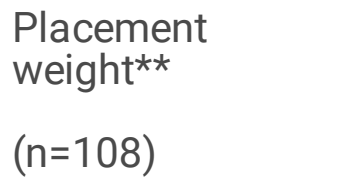 & $40.26^{c} \pm 0.28$ & $40.9^{b c_{ \pm}} 0.25$ & $42.24^{\mathrm{a}} \pm 0.23$ & $41.10^{\mathrm{b}} \pm 0.21$ & $40.26^{c} \pm 0.28$ \\
\hline $\begin{array}{l}\text { Transit weight } \\
\text { loss }^{N S} \\
(n=108)\end{array}$ & $3.69 \pm 0.39$ & $3.58 \pm 0.12$ & $2.94 \pm 0.10$ & $3.25 \pm 0.15$ & $3.32 \pm 0.11$ \\
\hline
\end{tabular}

NS-Not significant, *-Significant $(P<0.05)$, **-Highly significant $(P<0.01)$, Mean values within each row having common superscripts don't differ significantly, $n=$ Number of observations 
Table 3 Effect of in ovo feeding of arginine, tryptophan and their combination on weekly body weight gain (g) (Mean \pm S.E).

\begin{tabular}{|llllll|}
\hline Week & Treatments & & & & \\
\cline { 2 - 6 } & Control & $\begin{array}{l}\text { Injected } \\
\text { control }\end{array}$ & $\begin{array}{l}\text { Arginine } \\
\text { (Arg) }\end{array}$ & $\begin{array}{l}\text { Tryptophan } \\
\text { (Trp) }\end{array}$ & $\begin{array}{l}\text { Combination } \\
\text { (Arg+Trp) }\end{array}$ \\
\hline $\begin{array}{l}\text { First } \\
(n=96)\end{array}$ & $43.33 \pm 0.94$ & $45.04 \pm 0.88$ & $44.68 \pm 0.90$ & $42.40 \pm 0.81$ & $43.08 \pm 0.64$ \\
\hline $\begin{array}{l}\text { Second* } \\
(n=96)\end{array}$ & $164.35^{\mathrm{b}} \pm 4.04$ & $170.30^{\mathrm{b}} \pm 3.49$ & $181.37^{\mathrm{a}} \pm 2.95$ & $169.84^{\mathrm{b}} \pm 3.43$ & $173.26^{\mathrm{ab}} \pm 3.82$ \\
\hline $\begin{array}{l}\text { Third**} \\
(\mathrm{n}=94)\end{array}$ & $308.36^{\mathrm{b}} \pm 7.89$ & $305.28^{\mathrm{b}} \pm 5.36$ & $334.15^{\mathrm{a}} \pm 5.03$ & $310.94^{\mathrm{b}} \pm 6.07$ & $312.90^{\mathrm{b}} \pm 6.15$ \\
\hline $\begin{array}{l}\text { Fourth } \\
(\mathrm{n}=84)\end{array}$ & $457.69 \pm 6.72$ & $462.76 \pm 7.59$ & $468.13 \pm 5.94$ & $448.53 \pm 10.31$ & $468.92 \pm 6.88$ \\
\hline $\begin{array}{l}\text { FifthNS } \\
(n=82)\end{array}$ & $317.24 \pm 10.30$ & $304.68 \pm 9.43$ & $309.84 \pm 9.93$ & $307.90 \pm 10.59$ & $313.62 \pm 9.26$ \\
\hline
\end{tabular}

NS - Not significant, ${ }^{\star}$ - Significant $(P<0.05),{ }^{*}$ - Highly significant $(P<0.01)$, Means within each row having common superscripts don't differ significantly, $n=$ Number of observations

Table 4 Effect of in ovo feeding of arginine, tryptophan and their combination on carcass traits $($ Mean $\pm S . E)(n=12)$.

\begin{tabular}{|llllll|}
\hline Variables (\%) & \multicolumn{2}{l}{ Treatments } & & & \\
& Control & $\begin{array}{l}\text { Injected } \\
\text { control }\end{array}$ & $\begin{array}{l}\text { Arginine } \\
\text { (Arg) }\end{array}$ & $\begin{array}{l}\text { Tryptophan } \\
\text { (Trp) }\end{array}$ & $\begin{array}{l}\text { Combination } \\
\text { (Arg+Trp) }\end{array}$ \\
\hline $\begin{array}{l}\text { New York dressed } \\
\text { weight }\end{array}$ & $91.85 \pm 0.18$ & $91.77 \pm 0.24$ & $91.62 \pm 0.23$ & $92.24 \pm 0.21$ & $91.73 \pm 0.23$ \\
\hline Eviscerated weight & $70.27^{\mathrm{b}} \pm 0.45$ & $70.19^{\mathrm{b}} \pm 0.71$ & $72.97^{\mathrm{a}} \pm 0.28$ & $70.59^{\mathrm{b}} \pm 0.43$ & $71.56^{\mathrm{b}} \pm 0.50$ \\
\hline $\begin{array}{l}\text { Ready to cook } \\
\text { weight }^{\star *}\end{array}$ & $76.58^{\mathrm{b}} \pm 0.62$ & $76.47^{\mathrm{b}} \pm 0.75$ & $79.72^{\mathrm{a}} \pm 0.45$ & $76.73^{\mathrm{b}} \pm 0.34$ & $77.48^{\mathrm{b}} \pm 0.66$ \\
\hline Giblets $^{\mathrm{NS}}$ & $6.30 \pm 0.24$ & $6.28 \pm 0.25$ & $6.74 \pm 0.45$ & $6.14 \pm 0.25$ & $6.37 \pm 0.35$ \\
\hline
\end{tabular}

NS-Not significant, **-Highly significant $(P<0.01)$, Means within each row having common superscripts don't differ significantly, $n=$ Number of observation

Table 5 Effect of in ovo feeding of arginine, tryptophan and their combination on cut up parts (Mean \pm S.E) $(n=12)$. 


\begin{tabular}{|c|c|c|c|c|c|}
\hline \multirow{2}{*}{$\begin{array}{l}\text { Cut up parts } \\
(\%)\end{array}$} & \multicolumn{5}{|l|}{ Treatments } \\
\hline & Control & $\begin{array}{l}\text { Injected } \\
\text { control }\end{array}$ & $\begin{array}{l}\text { Arginine } \\
\text { (Arg) }\end{array}$ & $\begin{array}{l}\text { Tryptophan } \\
\text { (Trp) }\end{array}$ & $\begin{array}{l}\text { Combination } \\
\text { (Arg+Trp) }\end{array}$ \\
\hline Breast* & $30.50^{b} \pm 0.68$ & $31.14^{b} \pm 0.35$ & $31.52^{\mathrm{ab}} \pm 1.15$ & $33.09^{a} \pm 0.40$ & $32.75^{\mathrm{a}} \pm 0.35$ \\
\hline Back $^{N S}$ & $22.43 \pm 0.65$ & $22.12 \pm 0.50$ & $22.18 \pm 0.44$ & $21.80 \pm 0.32$ & $21.67 \pm 0.32$ \\
\hline ThighNS $^{N S}$ & $13.97 \pm 0.51$ & $14.44 \pm 0.25$ & $14.19 \pm 0.30$ & $14.15 \pm 0.26$ & $14.0 \pm 0.28$ \\
\hline Drumstick $^{N S}$ & $14.81 \pm 0.82$ & $14.24 \pm 0.98$ & $14.11 \pm 0.59$ & $14.71 \pm 0.30$ & $15.36 \pm 0.47$ \\
\hline Wing $^{\text {NS }}$ & $11.02 \pm 0.57$ & $11.74 \pm 0.16$ & $10.47 \pm 0.46$ & $10.82 \pm 0.31$ & $10.87 \pm 0.43$ \\
\hline $\mathrm{Neck}^{\mathrm{NS}}$ & $3.63 \pm 0.51$ & $3.44 \pm 0.19$ & $3.05 \pm 0.23$ & $3.31 \pm 0.17$ & $3.11 \pm 0.11$ \\
\hline
\end{tabular}

NS-Not significant, *-Significant $(\mathrm{P}<0.05)$, Mean values within each row bearing common superscripts do not differ significantly, $n=$ Number of observations

Table 6 Effect of in ovo feeding of arginine, tryptophan and their combination on glycogen $(\boldsymbol{\mu g})$ status $(M e a n \pm S . E)(n=12)$.

\begin{tabular}{|lll|}
\hline Treatment & $\mathbf{4}^{\text {th }}$ day** & $\mathbf{2 1}^{\text {st }}$ day** \\
\hline Control & $04.61^{\mathrm{b}} \pm 0.97$ & $3.35^{\mathrm{b}} \pm 0.60$ \\
\hline Injected control & $13.66^{\mathrm{a}} \pm 0.70$ & $3.17^{\mathrm{b}} \pm 0.93$ \\
\hline Arginine & $18.52^{\mathrm{a}} \pm 1.92$ & $7.54^{\mathrm{a}} \pm 0.20$ \\
\hline Tryptophan & $06.73^{\mathrm{b}} \pm 0.42$ & $3.37^{\mathrm{b}} \pm 0.52$ \\
\hline Combination (Arg+Trp) & $11.54^{\mathrm{a}} \pm 2.39$ & $4.76^{\mathrm{b}} \pm 1.13$ \\
\hline F value & 12.194 & 6.043 \\
\hline
\end{tabular}

$\star *_{\text {- Highly significant }(}(\mathrm{C}<0.01)$

Mean values within each column bearing common superscripts do not differ significantly

$\mathrm{n}=$ Number of observations

Table 7 Effect of in ovo feeding of arginine, tryptophan and their combination on intestinal morphometry $(\mu \mathrm{m})$ on $4^{\text {th }}$ day $(M e a n \pm S . E)(n=12)$. 


\begin{tabular}{lllll} 
Treatment & \multicolumn{2}{l}{ Duodenum } & & \\
\cline { 2 - 5 } & Villus height** & Mid villi width & Crypt depth** & Villus / Crypt ratio** \\
\hline Control & $835.5^{\mathrm{b}} \pm 26.41$ & $108.31 \pm 6.44$ & $88.20^{\mathrm{a}} \pm 11.30$ & $10.20^{\mathrm{c}} \pm 1.14$ \\
\hline Injected control & $873.89^{\mathrm{ab}} \pm 25.13$ & $97.73 \pm 4.49$ & $65.41^{\mathrm{b}} \pm 7.84$ & $23.35^{\mathrm{a}} \pm 2.13$ \\
\hline Arginine & $938.28^{\mathrm{a}} \pm 18.15$ & $107.26 \pm 4.92$ & $41.78^{\mathrm{c}} \pm 3.69$ & $14.17^{\mathrm{bc}} \pm 1.37$ \\
\hline Tryptophan & $906.13^{\mathrm{a}} \pm 23.24$ & $104.67 \pm 5.01$ & $56.19^{\mathrm{bc}} \pm 3.33$ & $16.48^{\mathrm{b}} \pm 1.31$ \\
\hline Combination & $907.59^{\mathrm{a}} \pm 14.16$ & $102.28 \pm 3.92$ & $69.71^{\mathrm{ab}} \pm 5.43$ & $13.40^{\mathrm{bc}} \pm 1.02$ \\
(Arg+Trp) & & & &
\end{tabular}

\section{Jejunum}

Villus height $^{\text {NS } \quad \text { Mid villi width }}{ }^{\text {NS }}$ Crypt depth ${ }^{\text {NS }} \quad$ Villus / Crypt ratio ${ }^{\text {NS }}$

\begin{tabular}{lllll}
\hline Control & $504.48 \pm 9.49$ & $71.23 \pm 1.83$ & $65.78 \pm 7.56$ & $8.12 \pm 0.74$ \\
\hline Injected control & $589.54 \pm 63.46$ & $75.17 \pm 7.36$ & $59.00 \pm 5.01$ & $10.75 \pm 2.03$ \\
\hline Arginine & $556.47 \pm 25.17$ & $68.82 \pm 3.00$ & $64.35 \pm 6.70$ & $9.02 \pm 0.82$ \\
\hline Tryptophan & $534.09 \pm 38.45$ & $76.73 \pm 5.90$ & $71.52 \pm 2.99$ & $7.45 \pm 0.45$ \\
\hline Combination & $513.04 \pm 37.82$ & $82.18 \pm 8.36$ & $70.34 \pm 5.38$ & $7.43 \pm 0.61$ \\
(Arg + Trp) & & & &
\end{tabular}

\section{lleum}

\begin{tabular}{|c|c|c|c|c|}
\hline & Villus height* & Mid villi width ${ }^{\text {NS }}$ & Crypt depth NS & Villus / Crypt ratioNs \\
\hline Control & $439.08^{b} \pm 20.28$ & $68.87 \pm 6.21$ & $49.10 \pm 3.53$ & $6.85 \pm 0.53$ \\
\hline Injected control & $431.79^{b} \pm 30.03$ & $67.82 \pm 3.22$ & $49.62 \pm 5.30$ & $8.58 \pm 0.93$ \\
\hline Arginine & $526.02^{\mathrm{a}} \pm 39.52$ & $65.52 \pm 3.46$ & $61.23 \pm 5.94$ & $7.67 \pm 0.29$ \\
\hline Tryptophan & $531.02^{\mathrm{a}} \pm 23.20$ & $63.14 \pm 12.59$ & $63.36 \pm 3.22$ & $7.19 \pm 0.49$ \\
\hline $\begin{array}{l}\text { Combination } \\
\text { (Arg + Trp) }\end{array}$ & $531.79^{a} \pm 30.03$ & $68.89 \pm 5.38$ & $65.10 \pm 6.16$ & $6.74 \pm 0.26$ \\
\hline
\end{tabular}

NS- Not significant, *- Significant $(P<0.05)$, **- Highly significant $(P<0.01)$

Means within each column having common superscripts don't differ significantly $\mathrm{n}=$ Number of observations 
Table 8 Effect of in ovo feeding of arginine, tryptophan and their combination on intestinal morphometry $(\mu \mathrm{m})$ on $35^{\text {th }}$ day (Mean \pm S.E) $(n=12)$. 


\begin{tabular}{|c|c|c|c|c|}
\hline \multirow[t]{2}{*}{ Treatments } & \multicolumn{4}{|l|}{ Duodenum } \\
\hline & Villus height** & Mid villi width* & Crypt depth ${ }^{\text {NS }}$ & $\begin{array}{l}\text { Villus/Crypt } \\
\text { ratio }^{\text {NS }}\end{array}$ \\
\hline Control & $1529.06^{\mathrm{ab}} \pm 79.40$ & $148.52^{\mathrm{C}} \pm 14.29$ & $81.20 \pm 17.70$ & $25.58 \pm 6.56$ \\
\hline Injected control & $1488.58^{\mathrm{b}} \pm 65.21$ & $163.88^{b c} \pm 21.98$ & $103.84 \pm 7.20$ & $14.86 \pm 1.58$ \\
\hline Arginine & $1469.37^{b} \pm 183.95$ & $194.57^{a b c} c_{ \pm} 11.54$ & $88.28 \pm 9.33$ & $16.60 \pm 1.12$ \\
\hline Tryptophan & $1796.24^{\mathrm{ab}} \pm 25.59$ & $227.27^{\mathrm{b}} \pm 15.17$ & $97.69 \pm 8.49$ & $19.14 \pm 1.75$ \\
\hline \multirow{3}{*}{$\begin{array}{l}\text { Combination } \\
\text { (Arg+Trp) }\end{array}$} & $1845.86^{\mathrm{a}} \pm 119.87$ & $205.16^{\mathrm{ab}} \pm 22.14$ & $112.19 \pm 10.21$ & $16.89 \pm 1.35$ \\
\hline & \multicolumn{4}{|l|}{ Jejunum } \\
\hline & Villus height** & Mid villi width** & Crypt depthNS & $\begin{array}{l}\text { Villus/Crypt } \\
\text { ratio }^{\text {NS }}\end{array}$ \\
\hline Control & $1412.10^{b c} \pm 124.93$ & $133.70^{\mathrm{b}} \pm 16.62$ & $116.92 \pm 15.14$ & $13.41 \pm 2.28$ \\
\hline Injected control & $1212.34^{\mathrm{C}} \pm 137.22$ & $136.91^{\mathrm{b}} \pm 14.01$ & $128.52 \pm 8.93$ & $9.50 \pm 0.95$ \\
\hline Arginine & $1161.97^{c} \pm 106.41$ & $158.12^{b} \pm 14.63$ & $97.44 \pm 5.05$ & $11.83 \pm 0.59$ \\
\hline Tryptophan & $1624.71^{a b} \pm 52.61$ & $162.66^{\mathrm{ab}} \pm 11.30$ & $112.19 \pm 5.30$ & $14.70 \pm 1.07$ \\
\hline \multirow{3}{*}{$\begin{array}{l}\text { Combination } \\
\text { (Arg + Trp) }\end{array}$} & $1777.52^{\mathrm{a}} \pm 125.02$ & $202.13^{\mathrm{a}} \pm 14.78$ & $130.24 \pm 14.92$ & $14.93 \pm 2.32$ \\
\hline & \multicolumn{4}{|l|}{ lleum } \\
\hline & Villus height ${ }^{N S}$ & Mid villi widthNS & Crypt depth NS & $\begin{array}{l}\text { Villus/Crypt } \\
\text { ratio }^{\text {NS }}\end{array}$ \\
\hline Control & $862.03 \pm 23.70$ & $135.44 \pm 19.59$ & $126.70 \pm 15.90$ & $7.45 \pm 1.08$ \\
\hline Injected control & $1234.01 \pm 230.42$ & $120.85 \pm 18.74$ & $95.25 \pm 6.62$ & $13.74 \pm 3.17$ \\
\hline Arginine & $1310.34 \pm 182.59$ & $138.58 \pm 15.73$ & $103.26 \pm 9.76$ & $13.71 \pm 2.89$ \\
\hline Tryptophan & $880.68 \pm 38.61$ & $127.23 \pm 7.54$ & $86.40 \pm 6.77$ & $10.45 \pm 0.82$ \\
\hline $\begin{array}{l}\text { Combination } \\
\text { (Arg + Trp) }\end{array}$ & $891.27 \pm 73.00$ & $139.26 \pm 12.52$ & $108.58 \pm 9.80$ & $8.84 \pm 1.52$ \\
\hline
\end{tabular}

NS- Not significant, *-significant $(P<0.05),{ }^{*}$ - Highly significant $(P<0.01)$ 
Means within each column bearing common superscripts don'ot differ significantly $\mathrm{n}=$ Number of observations

\section{Figures}

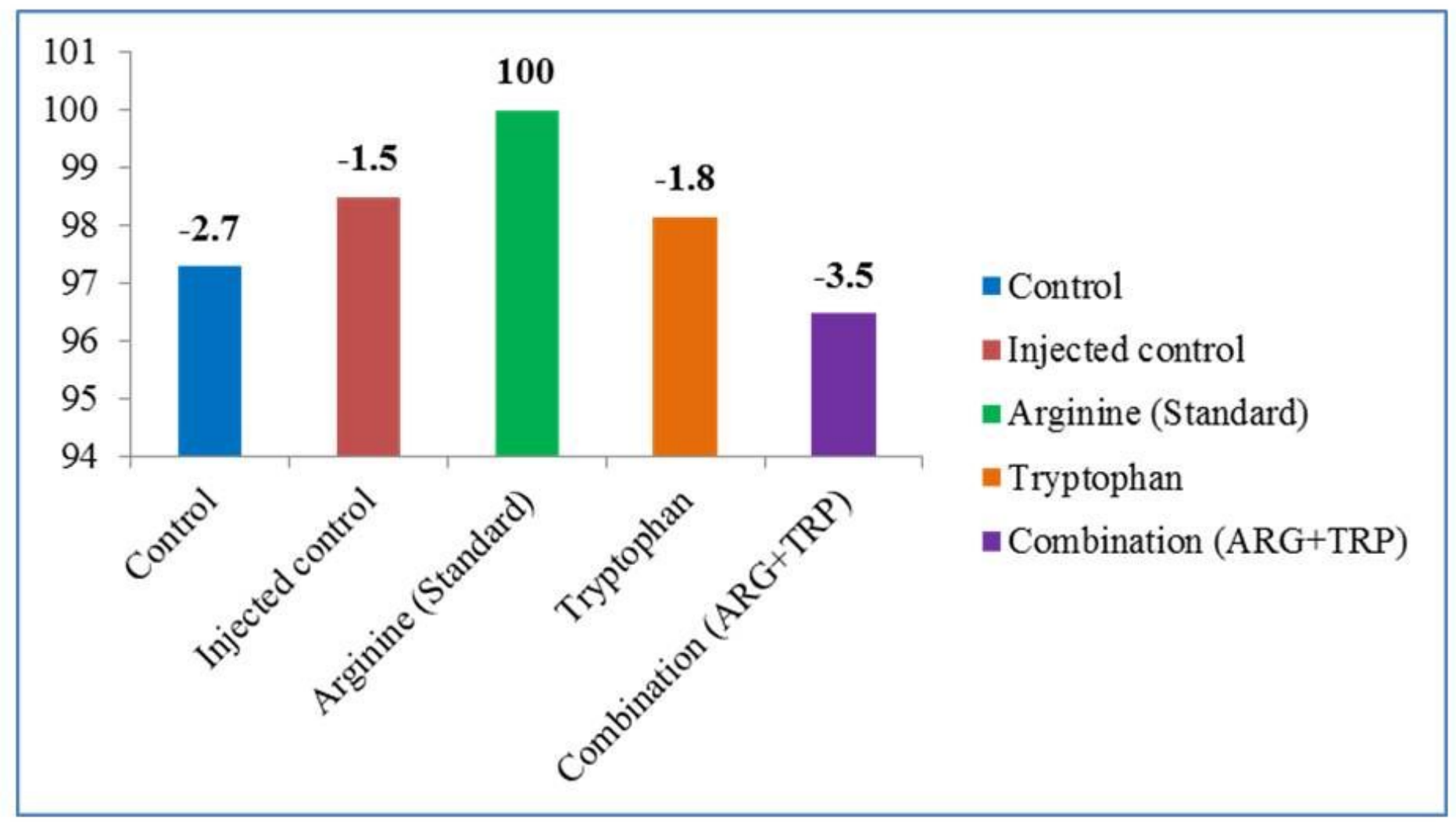

Figure 1

Per cent variation in hatch weight relative to arginine treatment. 


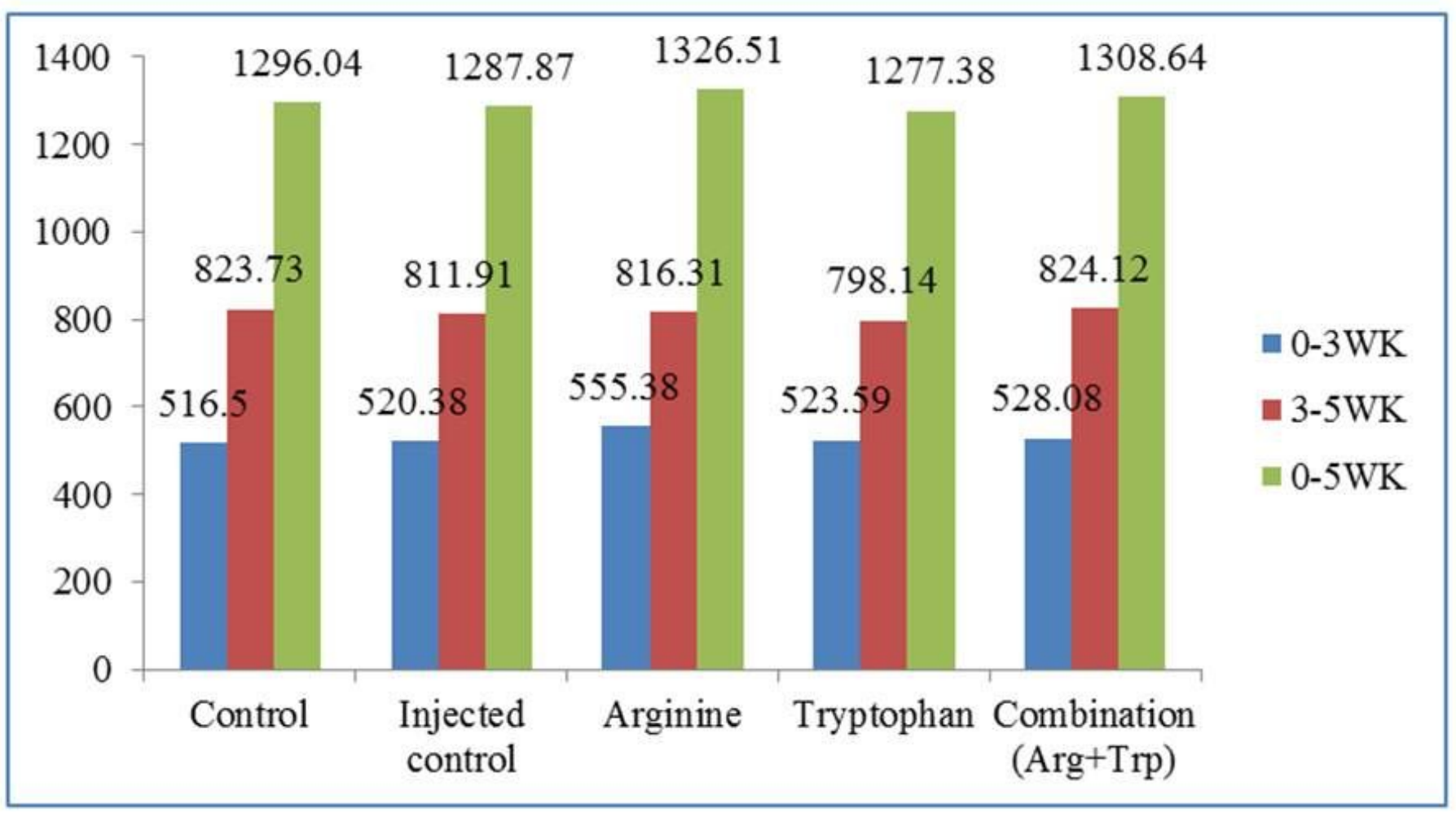

Figure 2

Effect of in ovo feeding of arginine, tryptophan and their combination on body weight gain in three periods (0-3, 3-5 and 0-5weeks). 


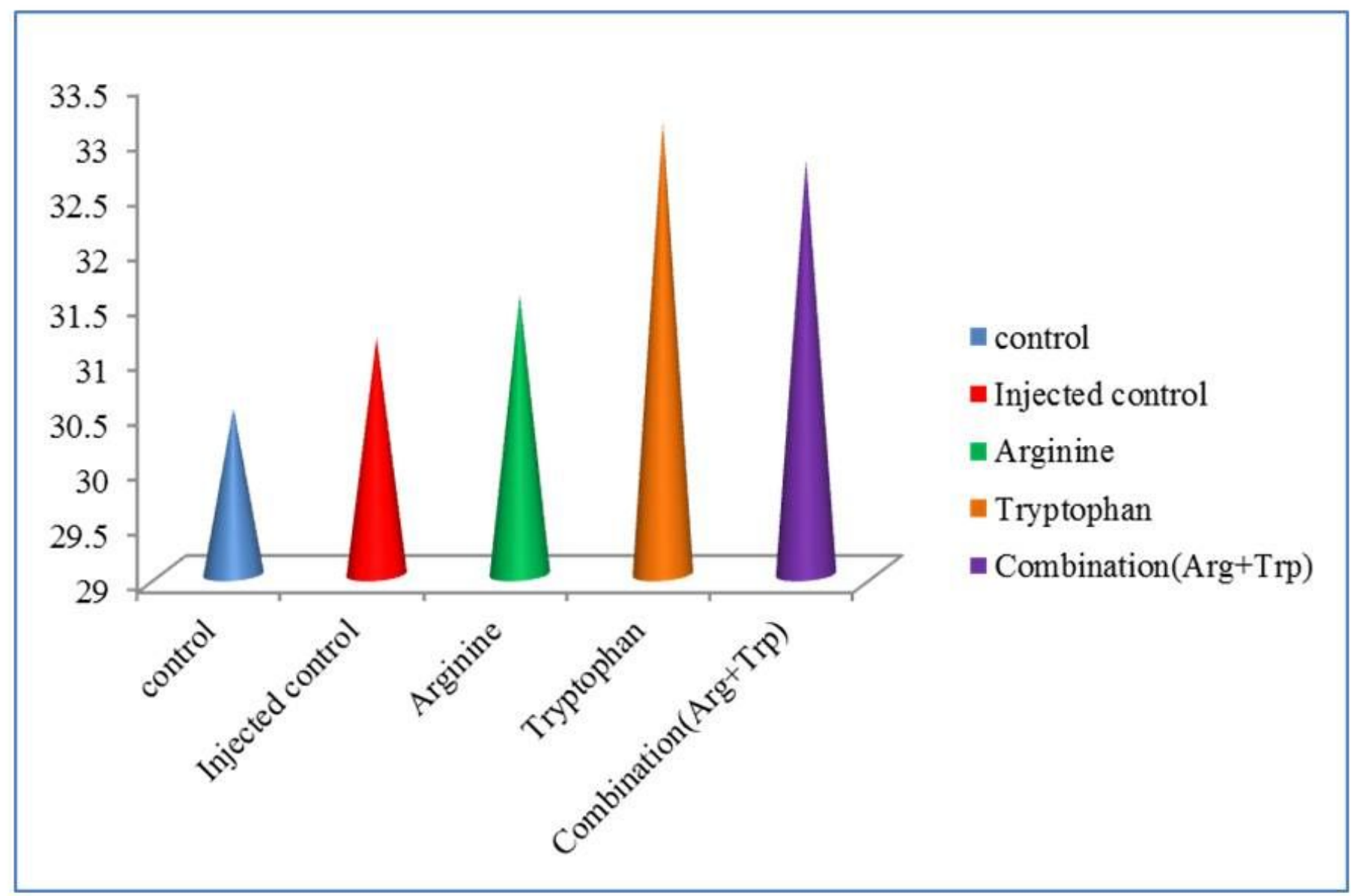

Figure 3

Effect of in ovo feeding of arginine, tryptophan and their combination on the per cent of breast yield in relation to eviscerated weight. 


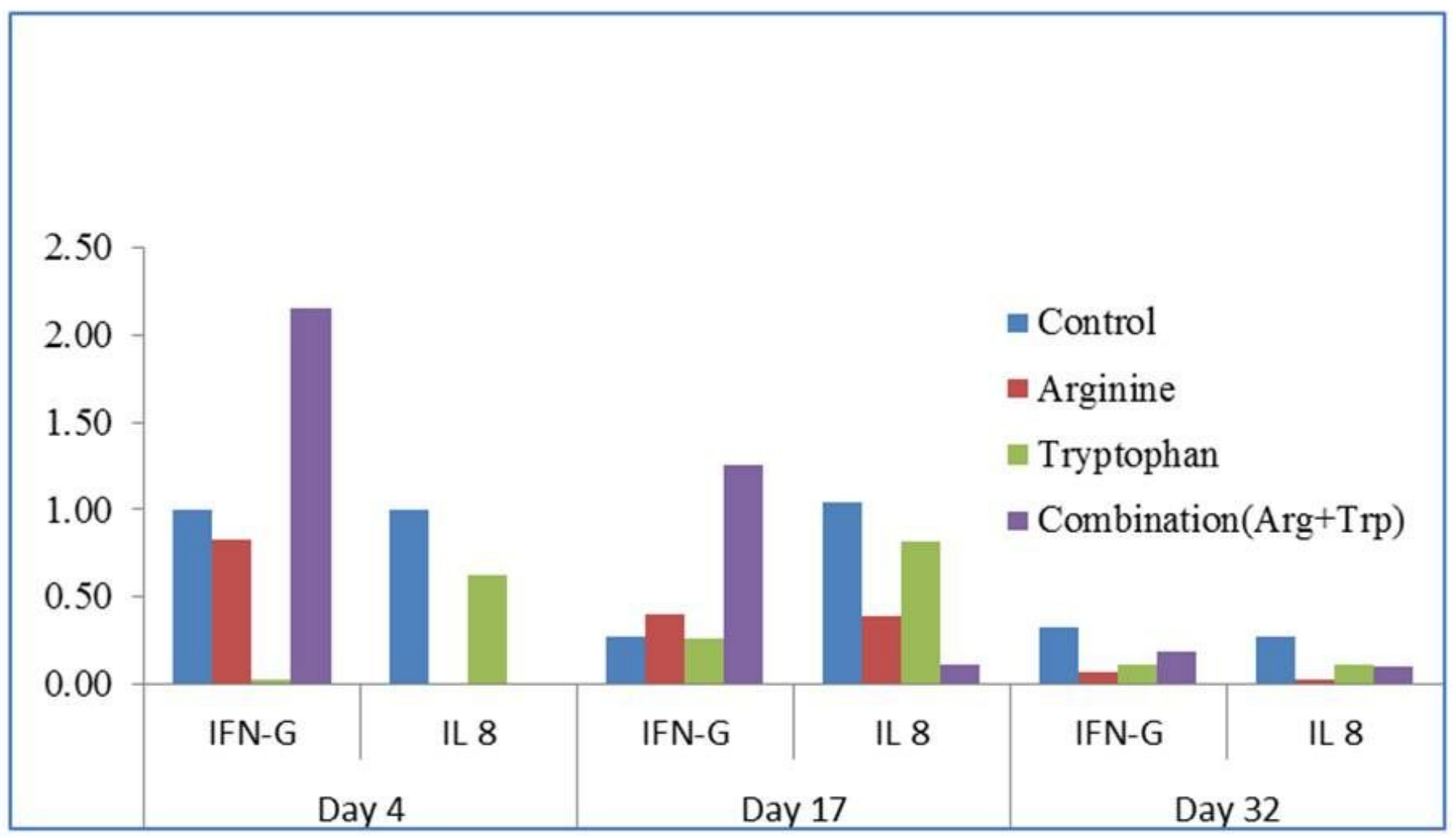

Figure 4

Effect of in ovo feeding of arginine, tryptophan and their combination on expression of IL-8 and IFN-Y gene in splenocytes. 


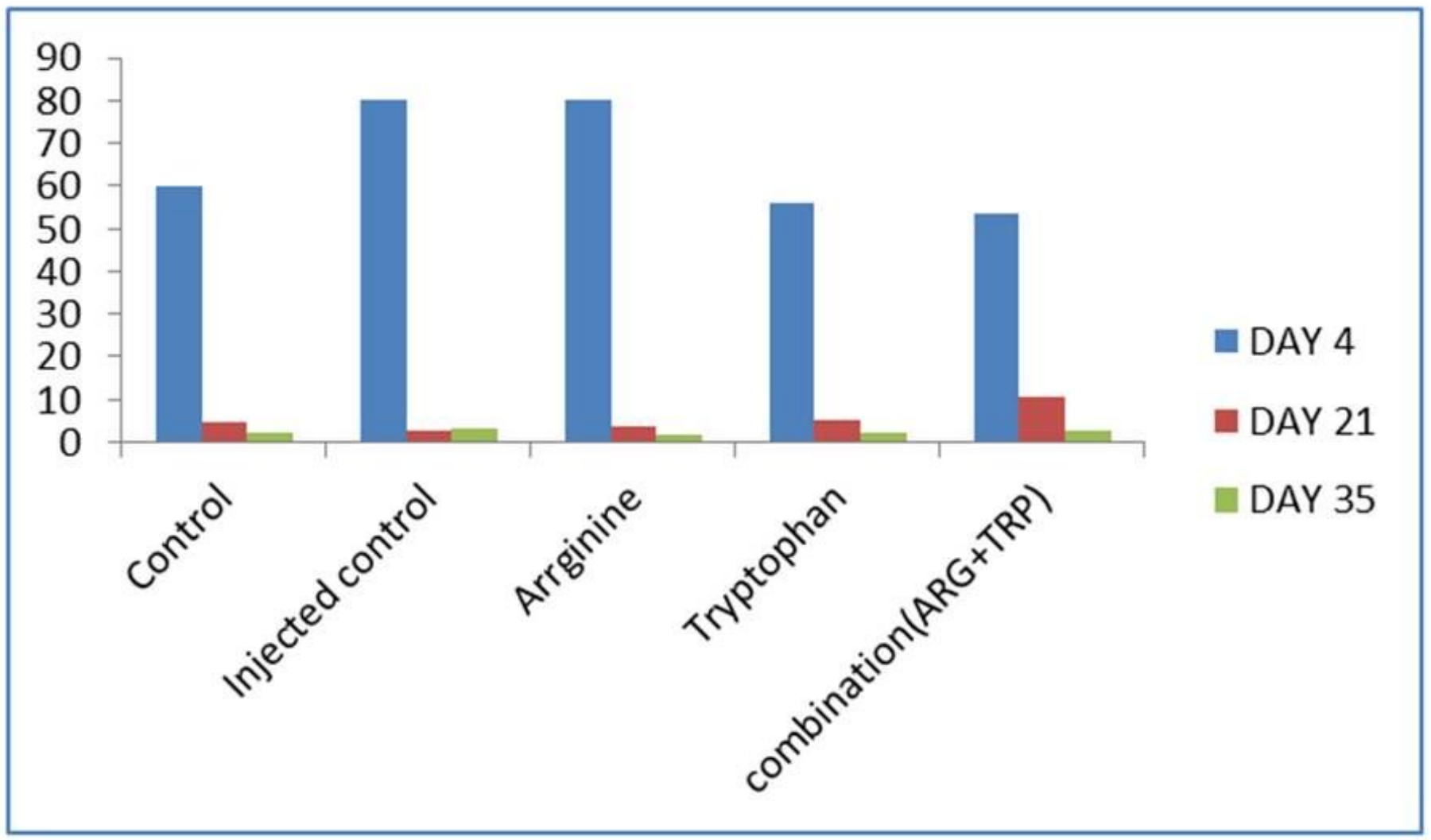

Figure 5

Effect of in ovo feeding of arginine, tryptophan and their combination on graphical representation of $\mathrm{HI}$ titre against ND virus. 